have digital skills below the baseline level, in particular, $15 \%$ of Ukrainians do not have digital skills at all. A $47 \%$ of citizens are interested in digital skills.

The passage of the CPD will not give the $\mathrm{CCH}$ doctor guaranteed $100 \%$ positive result of the perception of the information received. In this connection, the obtained information must be constantly implemented in practice in $\mathrm{CCH}$.

Thus, the expansion of professional competencies as a result of continuous medical education should occur not only at the expense of the acquisition of new knowledge, skills and skills, as well as at the expense of the development of the personal qualities of the doctor, abilities and motivation.

\title{
References:
}

1. Borshch V., Shchur R., Chuvakov O. Motivation and stimulation mechanism of medical staff indeveloping countries: main challenges and ways of its improving in Ukraine. Baltic Journal of economic studies. 2018. Vol. 4. No 4. P. 56-61.

2. Androukh V.S., Androukh V.N., Slobodian M.V. Modern aspects of continuing professional development of Ukrainian doctors in the field of health care The practitioner. 2019. Vol. 8, №. 2(30). P. 5-8.

3. Tsyfrohram 2.0. Tsyfrova hramotnist ukraintsiv u rezhymi realnoho chasu: veb-sait. URL: https://ua.interfax.com.ua/news/blog/746434.html (access date: 25.05.2021).

DOI https://doi.org/10.30525/978-9934-26-121-3-9

\section{СУЧАСНІ ВИКЛИКИ У ПРОЦЕСІ ВЗАСМОДІЇ ДЕРЖАВИ ТА ГРОМАДЯНСЬКОГО СУСПІЛЬСТВА В УМОВАХ ДЕЦЕНТРАЛІЗАЦІЇ}

\author{
Динник I. П. \\ кандидат наук з державного управління, \\ асистент кафедри публічного управління та адміністрування \\ Київського начіонального торговельно-економічного університету \\ м. Київ, Україна
}

Важливим аспектом розвитку громадянського суспільства $\epsilon$ необхідність розвитку співпраці, партнерства між органами державної 
влади, органами місцевого самоврядування та ОГС, які би сприяли вирішенню суспільно значущих проблем, імплементації реформи децентралізації, що передбачає розширення і зміцнення прав та повноважень адміністративно-територіальних одиниць, ефективний контроль громадськості за діями влади.

Нинішній час ставить важливу для майбутнього країни проблему пошуку гармонійного поєднання інтересів бізнесу, громадянського суспільства, яке лише зароджується, і влади. Більше того, ні влада, ні бізнес як найбільш сильні компоненти тріади не зможуть трансформуватися в інтересах створення в країні цивілізованої ринкової і демократичної системи без участі в цьому процесі слабкого громадянського суспільства. Адже закономірним $є$ те, що внесок бізнес-структур у вирішення соціальних проблем суспільства повинен здійснюватися не тільки у вигляді спонсорської чи благодійної допомоги, спрямованої на покращення іміджу адміністративно-територіальних одиниць, а у вигляді цілісних, системних корпоративних соціальних програм.

Ці програми передбачають взаємодію бізнесу як 3 державою в цілому, так і з місцевими громадами та обов'язкову участь бізнесу у прийнятті рішень та їх реалізації, як на рівні окремих соціальних програм, так і на рівні національних проектів [1, с. 18-19];

- створенням системи соціального партнерства між органами державної влади, місцевого самоврядування та громадськими рухами, спрямованого на узгодження інтересів та вирішення проблем суспільства, передусім у соціально-економічній сфері. До сфери соціального партнерства входять: досягнення консенсусу з питань забезпечення зайнятості, створення додаткових робочих місць, організації оплачуваних громадських робіт, захисту населення від безробіття; застосування найманої праці 3 дотриманням техніки безпеки, вимог 3 охорони здоров'я працівників у процесі роботи, оплати праці та забезпечення відтворюючої і стимулюючої функцій заробітної плати, прав працівників на своєчасне отримання заробітної плати, забезпечення нормального режиму роботи та відпочинку, забезпечення права працівників на участь в управлінні роботою на підприємстві, в розподілі прибутку для забезпечення соціальної діяльності підприємства, у визначенні соціальних стандартів і встановленні їх мінімальних меж $[2$, с. 54,56$]$;

- запровадженням комунітарного підходу як доктрини, яка високо цінує спільне благо або ідеали спільного блага й обмежує прагнення до індивідуальної незалежності та самореалізації;

- «самоорганізацією громадянського суспільства як його динамічною властивістю, що проявляється у вигляді взаємодії 
громадян та їхніх об’єднань у процесі реалізації спільних (громадянських) ініціатив. Показниками наявності потужного самоорганізаційного потенціалу громадянського суспільства в Україні визначено громадянську ініціативу, ендогенно детермінований розвиток волонтерського руху, ефективно застосовувані інтернет-технології. Це якісно відрізняється від розуміння самоорганізації у контексті пояснення відносин як механічного поєднання інтересів, цілей, завдань на відміну від особливої форми самоорганізації громадянських засад на підставах кооперування (обміну) форм, способів, станів життєдіяльності» [3, c. 6-7];

- динамічною моделлю взаємодії держави та громадянського суспільства, що має високий потенціал для ведення ефективного консенсусного громадянського діалогу i передбачає: формування i формулювання національної ідеї; інформаційну відкритість діяльності органів державної влади; високий рівень громадянської політичної культури; чесність і професіоналізм державних службовців та службовців органів місцевого самоврядування;

- використанням концептуального підходу у центрі якого знаходиться потенціал інноваційних інформаційно-комунікаційних технологій як засобу масової комунікації із формуванням горизонтальних зв'язків віртуальної взаємодії влади із громадськістю, що потребує переорієнтації методів їхньої діяльності на задоволення потреб споживачів публічних послуг, переосмислення концепції управління суспільною інформацією з метою відновлення довіри людей до владних структур та забезпечення надійного зворотного зв'язку. Використання інтерактивних технологій через створення комунікативних майданчиків між суспільством і владою, організацію онлайн-доступу до проектів та діючої нормативно-правової бази, перенесення активності державних структур і окремих чиновників до соціальних структур і блогосферу кардинально змінює публічно-управлінський ландшафт. У цьому контексті е-демократія демонструє позаурядову траєкторію розвитку, автономність репрезентування суспільних інтересів.

Таким чином, визначивши місце децентралізації у процесах становлення громадянського суспільства через відповідні іiі політикоадміністративні фактори, актуалізується ціла низка питань пов'язаних iз розумінням суспільством громадської активності, основних тенденцій, що превалюють у розвитку ОГС в умовах сьогодення. I, звичайно, не менш важливими залишаються контроверсійні та складні виклики, які стоять на заваді суспільним змінам та розвитку інститутів громадянського суспільства. 


\title{
Література:
}

1. Баровська А. «Зрозуміла мова» / «plain language» у забезпеченні комунікативного зв'язку влада - громадськість на окупованих та звільнених територіях. URL: http://www.niss.gov.ua/content/articles/files/ language-35506.pdf. - Дата звернення: 11.07.2021.

2. Суспільство та влада: механізми взаємодії : навч.-метод. матеріали для слухачів дисципліни «Механізми взаємодії суспільства і влади» / А. М. Михненко, С.О. Кравченко, І. В. Пантелейчук та ін. К. : НАДУ, 2013. 80 c.

3. Матійчик А. В. Самоорганізація громадянського суспільства як чинник демократичної модернізації політичної системи України : дис. на здоб. наук. ступеня канд. політ. наук: спец. 23.00.02. ДВНЗ «Прикарпатський національний університет імені Василя Стефаника». Івано-Франківськ, 2016. 221 с.

\section{DOI https://doi.org/10.30525/978-9934-26-121-3-10}

\section{TAILORED MADE APPROACHES AND AGILE TECHNIQUES IN PUBLIC ADMINISTRATION}

\author{
Drobakhina T. O. \\ Postgraduate Student at the Department \\ of Management and Project Management \\ Dnipropetrovsk Regional Institute of Public Administration of the National \\ Academy of Public Administration under the President of Ukraine \\ Dnipro, Ukraine
}

The XX century has brought us a new creative economy and creative class that appeared as a core of this economy. New sector of the economy has introduced new specifics to the market where old approaches are not applicable and modern ones become essential. Creative industries are highly innovative, they are characterized by an abundance of micro-businesses and individuals spread across the arts, design, cultural, digital, entertainment and media sectors. As a consequence, they lack the capacity for strategic, cross sectoral research and development which, if properly recognized and supported, could propel growth. Sir Charlie Mayfield's productivity review highlighted how creative businesses face challenges because their outputs are primarily intangible, and in many cases unique. Though knowledgeintensive, they do not always meet the traditional requirements expected for 